\title{
Lateglacial and Postglacial Pioneers in Northern Europe
}

Edited by

Felix Riede

Miikka Tallaevaara

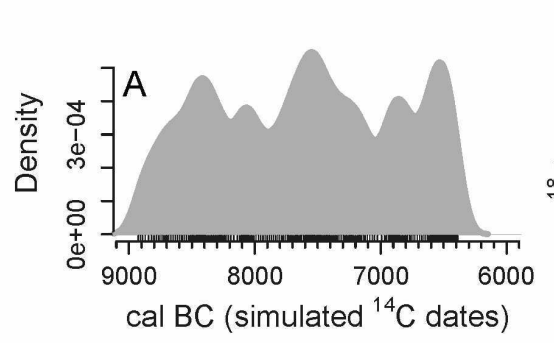

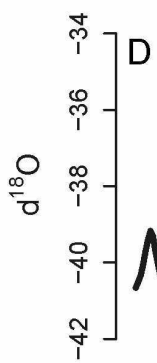
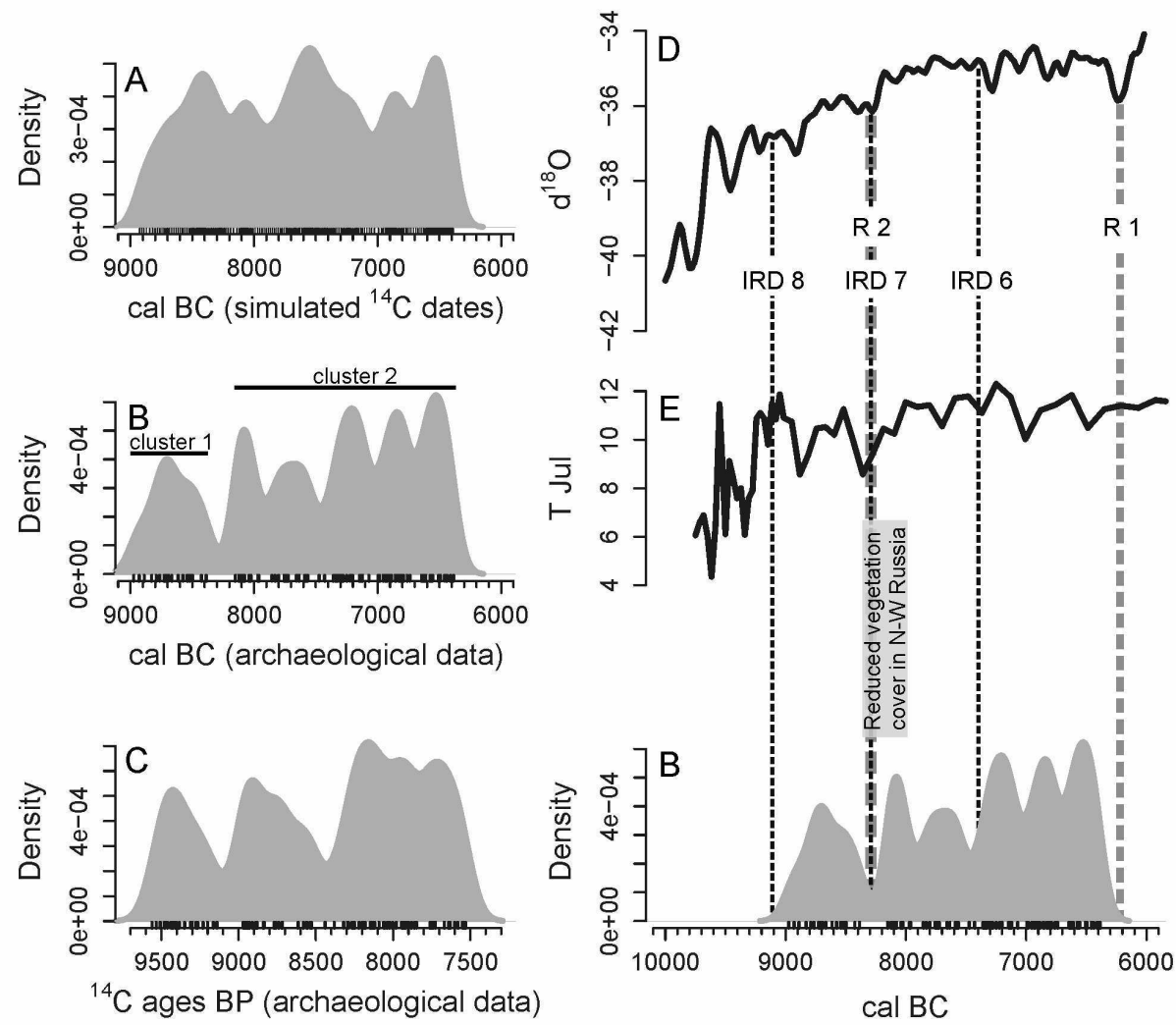

BAR International Series 2599

2014 


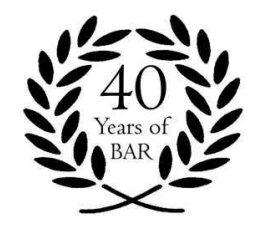

Published by

Archaeopress

Publishers of British Archaeological Reports

Gordon House

276 Banbury Road

Oxford OX2 7ED

England

bar@archaeopress.com

www.archaeopress.com

\section{BAR S2599}

Lateglacial and Postglacial Pioneers in Northern Europe

(C) Archaeopress and the indvidual authors 2014

ISBN 9781407312316

Printed in England by 4edge, Hockley

All BAR titles are available from:

Hadrian Books Ltd

122 Banbury Road

Oxford

OX2 7BP

England

www.hadrianbooks.co.uk

The current BAR catalogue with details of all titles in print, prices and means of payment is available free from Hadrian Books or may be downloaded from www.archaeopress.com 


\section{Contents}

\section{F. RIEDE \& M. TALLAVAARA}

1. The Lateglacial and postglacial pioneer colonisation of northern Europe - an introduction

\section{M.F. MORTENSEN, J. OLSEN, J. HOLM \& C. CHRISTENSEN}

2. Right time, right place

- dating the Havelte phase in Slotseng, Denmark.

\section{K.B. PEDERSEN}

3. On dating the Late Palaeolithic - a comment.

\section{F. RIEDE}

4. Success and failure during the Lateglacial pioneer human re-colonisation of southern Scandinavia.

\section{SOBKOWIAK-TABAKA}

5. The recolonisation of the Polish Lowland

- new ideas and discoveries.

K. PYŻEWICZ, W. MIGAL \& W. GRUŻDŹ

6. Magdalenian blade technology from the north-eastern

European perspective.

\section{P. GUSTAFSSON}

7. It is not all about quartz

- raw material use as a mean to understand colonization

processes during early post glacial time in Eastern Central Sweden.

F. MOLIN, G. GRUBER \& L. HAGBERG

8. Motala - a North European Focal Point?

M. PETTERSSON \& R. WIKELL

9. Where sky and sea are one. Close encounters with early seafarers and seal-hunters off the Swedish Baltic coast

\section{J.I. KLEPPE}

10. Desolate landscapes or shifting landscapes? Late glacial/early post-glacial settlement of northernmost Norway in the light of new data from Eastern Finnmark. 
J. KANKAANPÄÄ \& T. RANKAMA

11. Fast or Slow Pioneers? A View from Northern Lapland

M. TAlLAVA ARA, M.A. MANNINEN, P. PESONEN \& E. HERTELL

12. Radiocarbon dates and postglacial colonisation dynamics in eastern Fennoscandia

P. PESONEN, E. HERTELL, L. SIMPONEN, K. MANNERMAA,

M.A. MANNINEN, T. ROSTEDT, N. TAIPALE \& M. TALLAVAARA

13. Postglacial pioneer settlement in the Lake Sarvinki area, eastern Finland

H. TAKALA

14. Recent Archaeological Research in the Northern Parts of the Lake Ladoga Region in Karelia, Russia. 


\section{Postglacial pioneer settlement in the Lake Sarvinki area, eastern Finland}

\section{Petro Pesonen}

Department of Philosophy, History, Culture and Art Studies, P.O. Box 59, FI-00014 University of Helsinki, Finland and National Board of Antiquities, P.O.Box 913, FI-00101 Helsinki, Finland

petro.pesonen@gmail.com

\section{Esa Hertell}

Department of Philosophy, History, Culture and Art Studies, P.O. Box 59, FI-00014 University of Helsinki, Finland

ehertell@gmail.com

\section{Laija Simponen}

Department of Philosophy, History, Culture and Art Studies, P.O. Box 59, FI-00014 University of Helsinki, Finland

laija.simponen@helsinki.fi

\section{Kristiina Mannermaa}

Department of Philosophy, History, Culture and Art Studies, P.O. Box 59, FI-00014 University of Helsinki, Finland

kristiina.mannermaa@helsinki.fi

\section{Mikael A. Manninen}

Department of Philosophy, History, Culture and Art Studies, P.O. Box 59, FI-00014 University of Helsinki, Finland

mikael.manninen@helsinki.fi

\section{Tapani Rostedt}

Department of Archaeology, FI-20014 University of Turku, Finland tapaniro@hotmail.com

\section{Noora Taipale}

Service de Préhistoire, Quai Roosevelt 1B (bât A4) 4000 Liège, University of Liège, Belgium noora.taipale@ulg.ac.be

\section{Miikka Tallavaara}

Department of Philosophy, History, Culture and Art Studies, P.O. Box 59, FI-00014 University of Helsinki, Finland

miikka.tallavaara@helsinki.fi 
Abstract

In this contribution, we focus on the Lake Sarvinki area in eastern Finland and its position in the postglacial colonisation of Fennoscandia. Two sites (Rahakangas 1 and Jokivarsi 1) with radiocarbon dates reaching as far as c. 11,100-10,600 cal BP, contemporary to the late part of Yoldia Sea phase in the Baltic Sea basin, have been studied on a former lake shore. The excavations at Rahakangas 1 in 2009-10 concentrated in and around a house-pit. The main finds consist of a red ochre grave, burnt bones and chipped lithics. Radiocarbon determinations show three periods of site use, one in the Early Mesolithic, one in the Late Mesolithic and one in the Early Metal Period. The refuse fauna from Rahakangas 1 indicates a versatile use of animal resources. The collection of chipped lithics shows a similar pattern, and includes some exotic flints together with local quartz, quartzite and slate. Preserved tooth enamel of a child or a juvenile was found in the grave. Charcoal from the sand filling was dated to the Late Mesolithic, 8600-8408 cal BP. This makes it the oldest dated grave with preserved organic material in Finland and alsothe earliest piece of evidence that connects eastern Finland with the widespread tradition of using red ochre in burials. AMS-dates, artefacts and structures indicate a complex history of site use, and suggest shifts in foraging strategies, mobility, the length of site occupation, and the size and composition of the occupying group.

Keywords: Early Mesolithic, North Karelia, radiocarbon dates, flint blades, red-ochre grave, paleoenvironment, paleoeconomy

\section{Introduction}

Research on the initial settlement of Finland and eastern Fennoscandia has flourished during the most recent two decennia. Together with the improvements in AMS-dating - especially the possibility to obtain reliable dates from burnt bone - these investigations have led to the discovery of new sites and pushed back the date of the pioneer settlement several hundreds of years (e.g., Takala 2004; Pesonen 2005; Pesonen et al., in press; Jussila and Matiskainen 2003; Jussila et al., 2010). The available radiocarbon dates show that the earliest postglacial settlement in eastern Fennoscandia, c. 11,100-10,700 cal BP, concentrates in specific areas in eastern Finland, southern Finland and Russian Karelia (Fig. 1).

In the Lake Sarvinki area, several Mesolithic sites were discovered in the beginning of the 2000s and fieldwork has been carried out at the sites since 2009 . This paper deals with the results of the excavations conducted at the site Rahakangas 1 in 2009-2010 (see also Pesonen 2005; Pesonen et al., in press). Since 2011, also another Mesolithic site, Jokivarsi 1, has been subject to excavations. As the fieldwork continues, the results from this site will be published later.

The excavated area at Rahakangas 1 was only $49.5 \mathrm{~m}^{2}$, consisting of five trenches and a number of small test-pits. The excavation areas were positioned so that structural information about the potential house-pit observed at the site could be gained. On the basis of the evidence gathered during the excavations and the existence of several analogous house structures in eastern Fennoscandia (e.g., Pesonen 2002), it was possible to interpret the structure as a pit-house with a floor-area of $2.7 \times 4.2$ meters. Beneath the floor of the house, a red-ochre grave with fragments of tooth enamel from a child or a juvenile was detected. No other preserved prehistoric structures were discovered. The find material that forms the Mesolithic sequence of the site consists of flint artefacts including blades, quartz, slate, burnt animal bone, pieces of birch bark pitch and pieces of red ochre (Table 1). In addition, a few fragments of asbestos-tempered ceramics were discovered, probably of an Early Metal Period date.

The early dates and the presence of flint blades in the Sarvinki area point strongly towards post-Swiderian cultures, such as the Veretye and Butovo cultures of north-western Russia. In the present paper, three topics related to the Mesolithic settlement will be emphasised: 1) the paleoenvironment of the Sarvinki area and the relationship between ecological succession and the human settlement, 2) the lithic assemblage of the Rahakangas 1 site, and 3) the red ochre grave discovered at Rahakangas 1. Finally, the dynamics of site use and the settlement history of the area will be discussed. 


\section{Late Preboreal and Early Boreal radiocarbon dates in Finland}

At present, the sites Jokivarsi 1 and Rahakangas 1, both located in the Lake Sarvinki area, are the earliest radiocarbon-dated sites in Finland. Together with the dates from the Orimattila-Lahti region in Tavastia and the Kuurmanpohja region in South Karelia, the Sarvinki dates represent the earliest postglacial occupation of the country. The earliest dates extend to the
Late Preboreal period (Table 2). These sites, together with others that have produced early radiocarbondates (Table 3), form the four clusters of Late Preboreal sites known in Finland at the moment. Two early sites fall outside these clusters (Fig. 1).

The northernmost of the early sites, Sujala, is located in Utsjoki, northern Lapland. Sujala represents pioneer settlement from the post-Swiderian area, while the coast of the Arctic Ocean had been populated

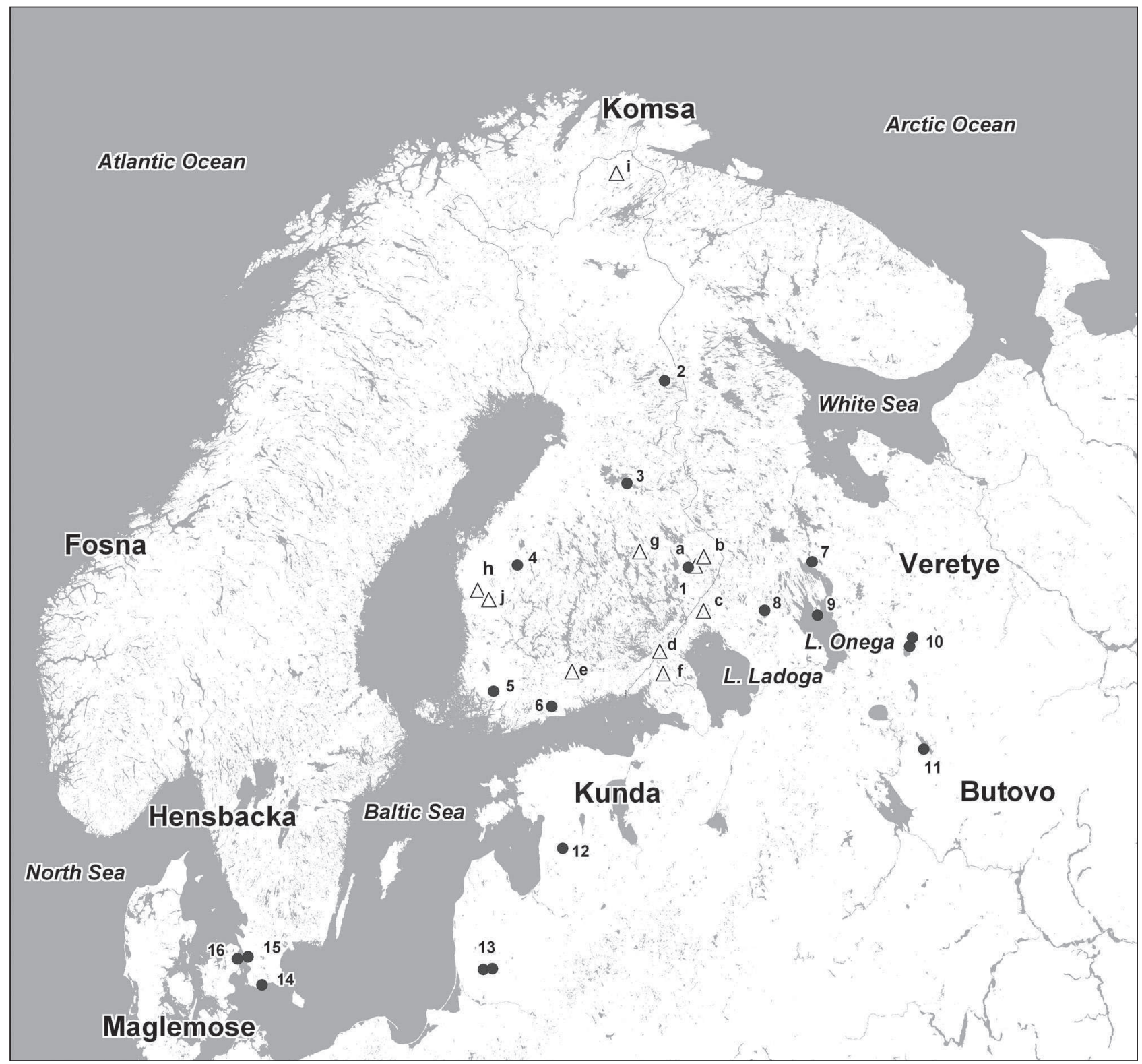

Figure 1. The location of the discussed Mesolithic sites in eastern Fennoscandia (a-j) and some Mesolithic burial grounds (1-16) in northern Europe: a) Rahakangas 1 and Jokivarsi 1, b) Syväys 1, c) Kirkkolahti 1, d) Saarenoja 2, e) Myllykoski, Ristola and Myllyoja, f) Korpilahti and Suuri Kelpojärvi, g) Helvetinhaudanpuro, h) Rimpikangas, i) Sujala, j) Hietaranta, 1) Rahakangas 1, 2) Jokela, 3) Äkälänniemi, 4) Haavistonharju, 5) Knaapin hiekkakuoppa, 6) Jönsas and Gröndal 2, 7) Chernaya guba, 8) Siamozero, 9) Oleniy ostrov, 10) Popovo and Peschanitsa, 11) Minino 1-2,12) Zvejnieki, 13) Spiginas and Duonkalnis, 14) Skateholm, 15) Tågerup, and 16) Vedbæk Bøgebakken. Some roughly contemporary Late Preboreal - Early Boreal cultures/technocomplexes are indicated for reference. 
Table 1. The find categories from the excavations at Rahakangas 1 site, 2009-2010. The artefacts are catalogued in the collections of the National Museum of Finland (NM 37962, NM 38399). Grinding plate fragments not included in the sum total count.

\begin{tabular}{|l|r|r|}
\hline Material & N & Weight (g) \\
\hline Flint & 50 & 11.3 \\
\hline Quartz & 1625 & 1027.2 \\
\hline -tools & 29 & 55.1 \\
\hline -cores & 5 & 64.5 \\
\hline -flakes & 1591 & 881.3 \\
\hline Quartzite flakes & 7 & 461.5 \\
\hline Slate & 15 & 249.9 \\
\hline -tools & 2 & 127.6 \\
\hline -flakes & 13 & 122.3 \\
\hline Grinding plate/fragments & 15 & c. 4500.0 \\
\hline Burnt bone & 9849 & 895.6 \\
\hline -tools & 4 & 1.4 \\
\hline -burnt bone fragments & 9845 & 894.2 \\
\hline Red ochre & 158 & 27.6 \\
\hline Asbestos & 4 & 1.0 \\
\hline Ceramics & 5 & 1.9 \\
\hline Birch bark pitch & 2 & 7.4 \\
\hline Other & $\mathbf{1 1 7 3 8}$ & 2.1 \\
\hline SUM & & $\mathbf{2 6 8 5 . 5}$ \\
\hline
\end{tabular}

earlier from the west (e.g., Kankaanpää and Rankama 2011; Rankama and Kankaanpää 2008). The Helvetinhaudanpuro site in Juankoski, North Savo, stands alone so far. It is dated to the same period as Sujala, but the Helvetinhaudanpuro material is quartz-dominated and only a minor portion of the lithics is flint or some other non-local stone (Jussila et al., 2007).

Together with the Kirkkolahti 1 site in at Lake Jänisjärvi, Russian Karelia, the Sarvinki sites form a cluster connected to the north-western expansion of the postglacial pioneer settlement. The Kirkkolahti 1 site has yielded only a few flints, but the site has so far been subjected only to a small-scale test excavation (Forsberg 2006). Other flint blade finds from eastern Finland, such as those from the multiperiod site Syväys 1 in Ilomantsi, may also date to the Late Preboreal (Hertell and Manninen 2006; Manninen and Hertell 2011).

The Kuurmanpohja region in Lappeenranta, South Karelia, includes several Mesolithic sites. Only one of these, Saarenoja 2, has so far yielded Late Preboreal

Table 2. The radiocarbon dates from the Sarvinki area. * Calibration with 95,4\% confidence level, OxCal v. 4.17 (Bronk Ramsey 2009), IntCal09 calibration curve (Reimer et al., 2009).

\begin{tabular}{|l|l|l|l|l|l|}
\hline Laboratory number & Site & Material/context & ${ }^{14} \mathbf{C}$ age BP & $\boldsymbol{\delta 1 3 C}(\% \circ)$ & Calibrated age* $^{*}$ \\
\hline Hela-2721 & Rahakangas 1 & burnt elk bone & $9533 \pm 56$ & -27.3 & $11,104-10,666$ \\
\hline Hela-2380 & Rahakangas 1 & burnt elk bone & $9461 \pm 61$ & -28.3 & $11,074-10,524$ \\
\hline Hela-882 & Rahakangas 1 & burnt elk bone & $9405 \pm 80$ & -28.1 & $11,071-10,407$ \\
\hline Hela-2720 & Rahakangas 1 & burnt beaver bone & $8038 \pm 47$ & -27.3 & $9079-8721$ \\
\hline Hela-2379 & Rahakangas 1 & charcoal (grave) & $7726 \pm 58$ & -27.0 & $8600-8408$ \\
\hline Hela-2719 & Rahakangas 1 & burnt fish bone & $1298 \pm 30$ & -26.1 & $1289-1177$ \\
\hline Ua-41027 & Jokivarsi 1 & burnt mammal bone & $9507 \pm 85$ & -27.3 & $11,130-10,575$ \\
\hline Ua-41028 & Kaiskunsärkkä 1 & burnt fish bone & $8055 \pm 64$ & -29.0 & $9131-8650$ \\
\hline
\end{tabular}

Table 3. Published Early Mesolithic radiocarbon dates from Finland and Russian Karelia predating 9000 BP (the dates from the Sarvinki area are excluded) (Takala 2004; Forsberg 2006; Jussila et al., 2007; Carpelan 2008; Kankaanpää and Rankama 2011). ${ }^{*}$ Calibration with 95,4 \% confidence level, OxCal v. 4.17 (Bronk Ramsey 2009), IntCal09 calibration curve (Reimer et al., 2009).

\begin{tabular}{|l|l|l|l|l|l|}
\hline Laboratory number & Site & Material/context & ${ }^{14}$ C age BP & $\boldsymbol{\delta 1 3 C}(\% \circ)$ & Calibrated age ${ }^{*}$ \\
\hline Hela-552 & Orimattila Myllykoski & burnt bone & $9480 \pm 90$ & -25.8 & $11,123-10,516$ \\
\hline Hela-728 & Lappeenranta Saarenoja 2 & burnt bone & $9350 \pm 75$ & -27.0 & $10,749-10,295$ \\
\hline Ua-24774 & Ruskeala Kirkkolahti 1 & burnt elk bone & $9300 \pm 85$ & -27.4 & $10,695-10,256$ \\
\hline Hel-1303 & Antrea Korpilahti & bark net float & $9290 \pm 140$ & $\mathrm{n} / \mathrm{a}$ & $11,070-10,198$ \\
\hline Hela-931 & Antrea Suuri Kelpojärvi & burnt bone & $9275 \pm 120$ & -26.6 & $11,052-10,201$ \\
\hline Hela-544 & Lahti Myllyoja & burnt bone & $9265 \pm 95$ & -26.4 & $10,680-10,241$ \\
\hline Hela-1102 & Utsjoki Sujala & charcoal (birch) & $9265 \pm 65$ & -27.6 & $10,644-10,251$ \\
\hline Hela-1442 & Utsjoki Sujala & charcoal (birch) & $9240 \pm 60$ & -27.5 & $10,561-10,254$ \\
\hline Hel-269 & Antrea Korpilahti & bark net float & $9230 \pm 210$ & $\mathrm{n} / \mathrm{a}$ & $11,155-9890$ \\
\hline Hela-918 & Juankoski Helvetinhaudanpuro & burnt elk bone & $9200 \pm 75$ & -24.9 & $10,557-10,233$ \\
\hline Hela-404 & Antrea Korpilahti & net bast & $9140 \pm 135$ & -29.5 & $10,680-9914$ \\
\hline Hela-1441 & Utsjoki Sujala & charcoal (birch) & $9140 \pm 60$ & -28.0 \\
\hline
\end{tabular}


dates. Due to its on-site flint blade production, the Saarenoja 2 site is perhaps the most important Early Mesolithic site in eastern Fennoscandia. The site is unique because of its high flint to quartz ratio (Jussila et al., 2010).

The Karelian Isthmus has a geographically central position when the migration of people from the southwest towards Finland is mapped. Not surprisingly, this area has yielded some of the earliest evidence of human settlement in eastern Fennoscandia. The famous net find from Antrea, located in the northern part of the isthmus, includes several bark net floats, pieces of net bast and a collection of bone, antler and stone artefacts (Pälsi 1920; Äyräpää 1951; Taavitsainen 1995; Carpelan 2008). The radiocarbon dates are in agreement with the dates from the nearby Suuri Kelpojärvi site. There are more sites in the Karelian Isthmus that probably date to the Early Mesolithic, and some also show signs of flint blade production in their lithic inventories (Takala 2004).

The western flank of the Early Mesolithic settlement in Finland is located in the valley of River Porvoonjoki where the earliest radiocarbon dated sites are Myllykoski site in Orimattila and Myllyoja site in Lahti. Neither of these sites has yielded flint, which, however, is present in the post-Swiderian inventory of the nearby Ristola site. It has been suggested that this region was first settled by representatives of the Kunda culture, i.e., people coming from the area that lies south of the Gulf of Finland (e.g., Edgren 1984; Takala 2004). More recently, it has been remarked that if flint is indicative of the origin of the early settlers, then an eastern or south-eastern direction is a more probable alternative as the Ristola collection is dominated by Carboniferous flint. Furthermore, flint varieties locally available and in use within the area of the Kunda culture have not been reported in the Ristola collection (Hertell and Tallavaara 2011).

\section{The environmental and economic setting}

\section{The paleogeography of the Sarvinki} area

The deglaciation of eastern Fennoscandia took several thousand years and major changes in the landscape, vegetation and wildlife took place during these millennia. Successive sea and lake phases, the major ones being the Baltic Ice Lake, the Yoldia Sea, the Ancylus Lake and the Littorina Sea, covered the Baltic Sea basin.

According to the traditional view, meltwater from the ice sheet formed the Baltic Ice Lake around the southern edge of the glacier. When the lowlands in southern Sweden became free of ice and a drainage channel opened, the water level of the Baltic Ice Lake dropped 25 meters reaching the level of the Atlantic Ocean. The following Yoldia Sea phase has been interpreted mostly as a fresh or brackish stage and it ended with the emergence of a threshold in Degerfors, Sweden. The subsequent Ancylus transgression initiated the Ancylus Lake phase of the Baltic Sea, beginning at $c$. 10,700 cal BP (e.g., Björck 1995; Tikkanen and Oksanen 2002). This view has been challenged by Påse and Anderson (2005), who doubt the very existence of the Baltic Ice Lake phase and rather call it the Baltic Ice Sea phase. According to their view, the Yoldia Sea was merely an extension of this phase. A marine connection during the whole melting period of the glacier, all the way to the onset of the Ancylus Lake phase, is thus indicated.

Whatever the degree of salinity in the southern part of the Baltic Sea, it obviously did not change the situation significantly in the northern parts of the sea where glacial meltwater streams kept the water relatively fresh (Påsse and Anderson 2005, 265; Tikkanen and Oksanen 2002). In eastern Finland the early phases of the Baltic Sea can be observed as ancient shore formations in the landscape. The regression of the Yoldia Sea was rapid and the subsequent Ancylus transgression could not have reached the old shorelines (e.g., Tikkanen and Oksanen 2002; Saarnisto 1970). Consequently, most of the lakes in the eastern Finland are derivatives of either local glacial lakes or the Yoldia Sea.

Lake Sarvinki was probably originally an ice lake that formed during the retreat of the Scandinavian Ice Sheet from the Salpausselkä II terminal moraine after c. 11,600 cal BP (Saarnisto and Saarinen 2001; Donner 2010). At present, the highest shorelines of the Baltic Sea are c. 105-106 meters above sea level in the Joensuu region (Hyvärinen and Rainio 2000; Saarnisto 1970), an altitude well below the level of ancient Lake Sarvinki, c. 112.5 meters above the pre- 


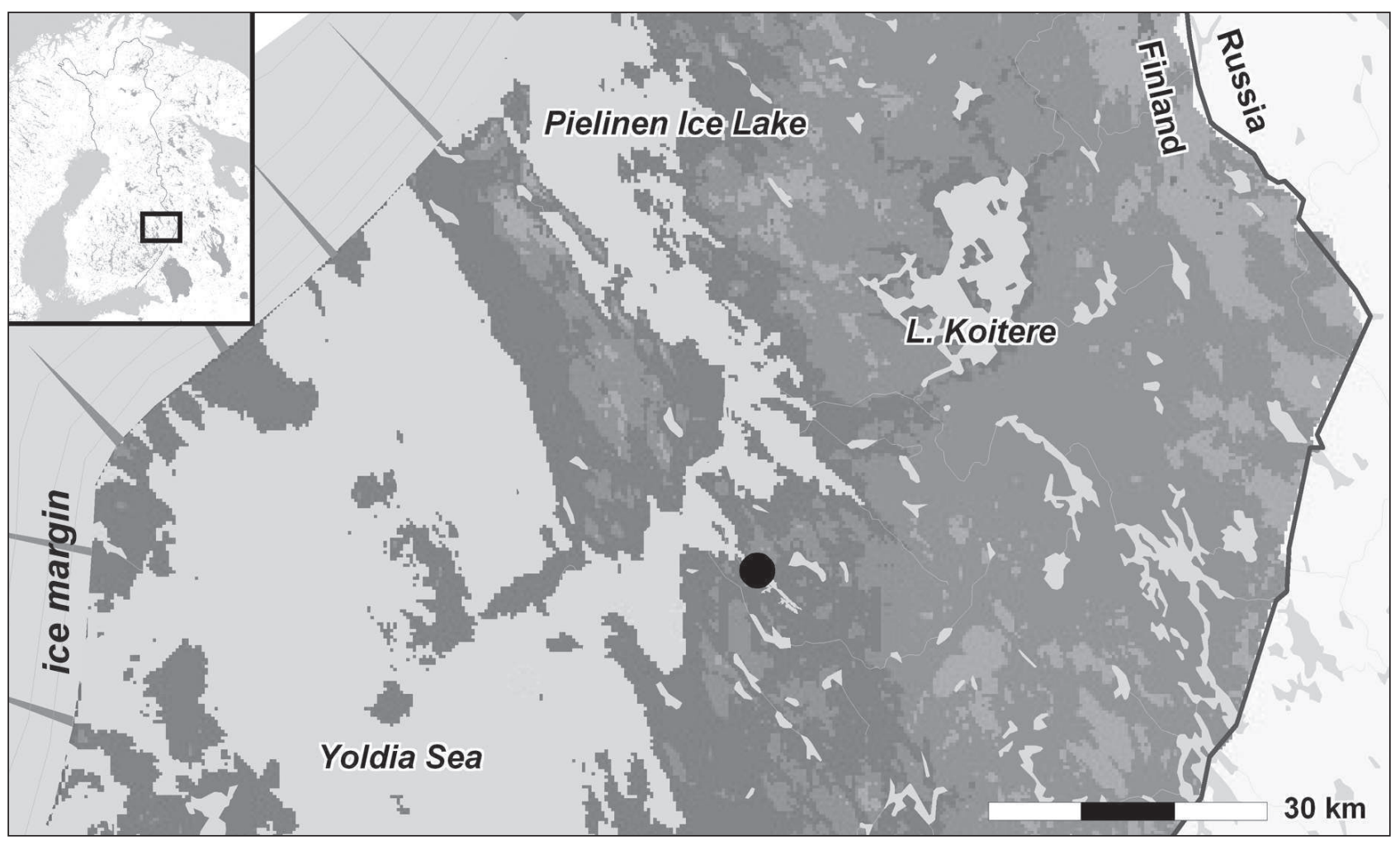

Figure 2. Paleogeography in North Karelia approximately 11000-10900 cal BP. First radiocarbon evidence of human activity in the Lake Sarvinki area (black dot) coincides with the final Yoldia phase of the Baltic Sea basin. Lake Sarvinki was connected to the Yoldia Sea and the Pielinen Ice Lake via a narrow outlet in the northwest. The shorelines and the position of the ice-margin according to Tikkanen and Oksanen (2002).

sent sea level. Lake Sarvinki has flown to Lake Jakojärvi via an outlet in its north-western end, known today as Lössänpuro (see Figs. 2 and 3). Lake Jakojärvi may have been a small bay of the Yoldia Sea before its isolation. Later it has been drained to River Pielisjoki. The Yoldia Sea reached the River Pielisjoki valley and Lake Pielinen for a period of time before its final regression and the subsequent formation of the separate lakes Pielinen and Pyhäselkä (a part of the Lake Saimaa complex), which are connected by River Pielisjoki (Fig. 2). Lake Pielinen was a glacial lake after its isolation from the Yoldia Sea (Miettinen 1996; Hyvärinen and Rainio 2000).

Lake Sarvinki remained stable until the 18th century AD. The postglacial history of the lake has not been studied with any precision, but a history of modest shore displacement can be inferred from the slightly differing altitudes of the prehistoric settlement sites. However, in 1743 the level of the Lake Sarvinki was lowered in hopes of gaining pasture and arable land on the shores of the lake. The attempt ended in a catastrophe when the drainage channel eroded its way through the ridge between lakes Sarvinki and Jakojärvi. Lake Sarvinki was completely drained except for a few small ponds that remained in its southeastern end. Lake Jakojärvi silted up and the former outlet of the Lake Sarvinki ran dry. There had been over 20 meters of water in the deepest spots of the former lake. Today the ancient lake bottom is mainly cultivated land and the old shores are forested (Vesajoki 1982; Myller 1999; Pesonen 2005).

\section{The paleovegetation}

There are no fine-resolution pollen studies devoted to the early postglacial vegetation history of eastern Fennoscandia. The picture we have of the vegetation history is therefore based on relatively old and incomplete information (Hyvärinen 1966; 1973). Generally speaking, the vegetation zones were tied to the advance of the deglaciation (Hyvärinen 1973; Matiskainen 1996). After the retreat of the Ice Sheet, the first vegetation consisted of grasses and shrubs. In a matter of decades this steppe-tundra environment turned into heaths dominated by small shrub- 


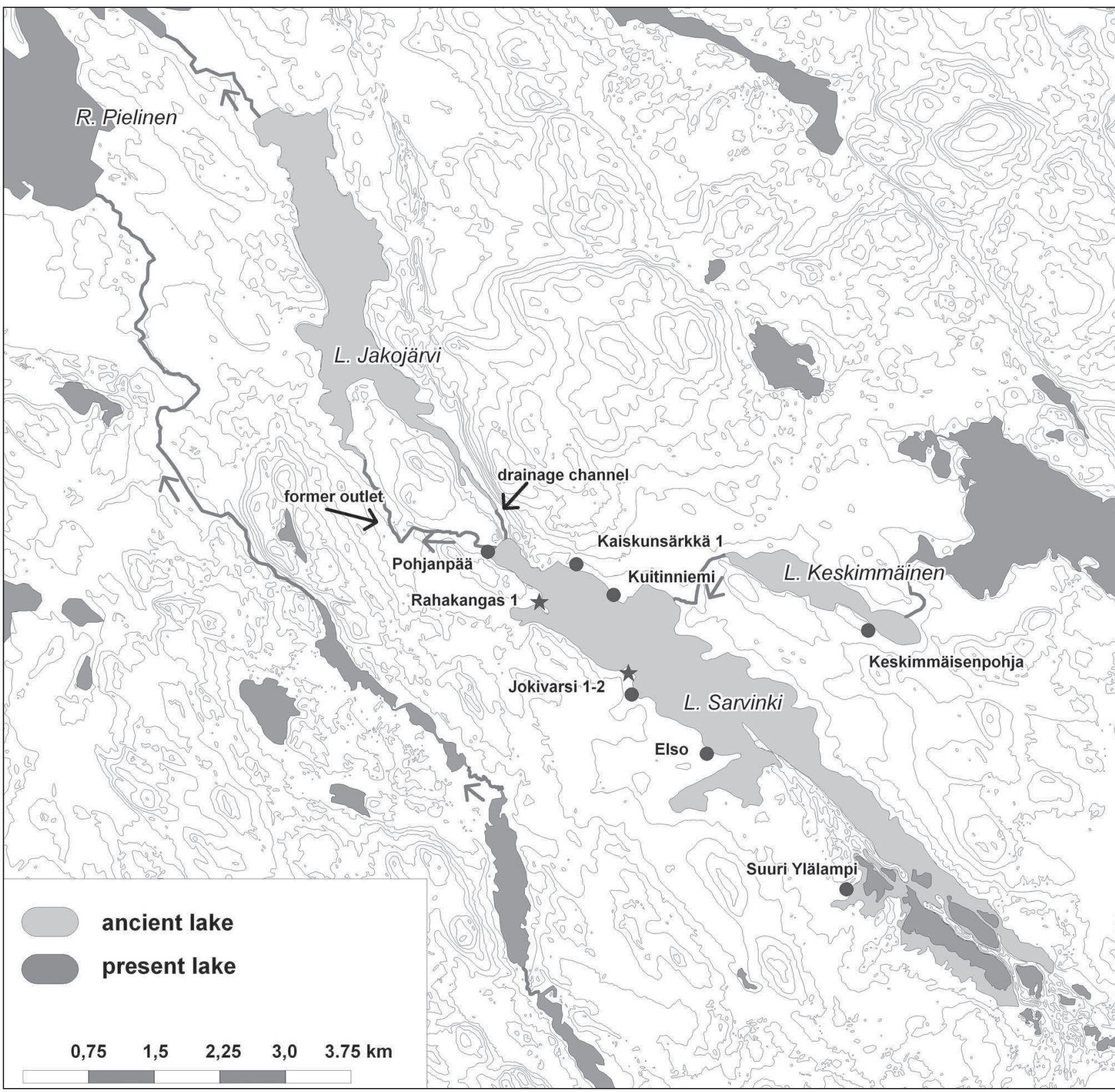

Figure 3. Paleogeography and Stone Age sites in the Lake Sarvinki area. Jokivarsi 1 and Rahakangas 1 (stars) have yielded Early Mesolithic dates (c. 11100-10400 cal BP) and Kaiskunsärkkä 1 as well as Rahakangas 1 later Mesolithic dates (c. 9100-8400 cal BP). Lake Sarvinki was drained in 1743 and Lake Jakojärvi was silted in the same event. Lake Keskimmäinen was drained in the 19th century.

like willow-species. According to current knowledge, the Sarvinki area was first occupied during the Late Preboreal, with birch as the dominant tree species. The shift from birch- to pine-dominant forest and to the Boreal climatic zone took place in the course of a few centuries. The study by Birks and Birks (2008) from western Norway illustrates the vegetational succession after the deglaciation. A comparison between the postglacial palynological turnover at a sample site and the floristic turnover in a recently deglaciated area showed similarities in all but one aspect: the ar- rival of birch. At the sample site, the arrival of birch dates to 670-720 years after the onset of the Holocene, while in the recent Little Ice Age glacier foreland birch arrived 200 years after the deglaciation. The reasons for the delay may be due to, for example, migrational delays, soil development or some other factors (Birks and Birks 2008, 27). In a recent study it was observed that there is a gap of $c .500$ years in eastern Finland and c. 900 years in northern Finland between the local deglaciation and the first human settlement (Tallavaara et al., this volume). One of the future chal- 
lenges is to get a grip on the actual date of the arrival of birch forest in these regions and to find out if there is a correlation between the arrival of the human settlement and the arrival of birch forest.

The soil development must also be taken into account, since the rapid regression of the Yoldia Sea would have created wide landscapes with unstable soils rich in clay and silt (Björck 1995, 27), difficult to settle for vegetation and humans alike. However, this problem would not have affected the colonisation of the deglaciated regions with small lakes further east.

\section{The paleoeconomy as reflected by the refuse fauna}

Deglaciation created an opportunity for animals to re-colonize eastern Fennoscandia. The immigration of mammals most probably took place directly from the east, from Siberia and through eastern Karelia (Ukkonen 2001; Rankama and Ukkonen 2001). The fish species in the inland lakes probably derive from the early Yoldia and Ancylus phases of the Baltic Sea basin, or from later colonisation (Koljonen 2008; Nurminen 2007).

The bone assemblage from Rahakangas 1 is diverse and contains aquatic, avian and terrestrial species (Table 4). The mammalian fauna includes species associated with young deciduous forests (e.g. Eurasian elk, Eurasian beaver, red fox), as well as species typical of coniferous or mixed forests (European pine marten). The bird taxa present at Rahakangas 1 do not point to a specific forest composition. Willow grouse and rock ptarmigan cannot be told apart in the burnt bone material. Willow grouse thrives both in deciduous and coniferous forests, although it moves into birch-dominated forests in the winter. Rock ptarmigan is an arctic bird which lives in the most northern treeless tundra and mountain areas. Divers and ducks are migratory birds which could have been hunted during spring, summer and autumn (e.g., Cramp et al., 1986). The fish species found at Rahakangas 1 are all common in the lakes of eastern Finland even today. The fishing season covers the whole year, even winter, when fish could have been caught through openings made in the ice cover.

It is likely that the Rahakangas 1 bone sample represents several hunting seasons, and multiple occupations. This is further confirmed by the radiocarbon dates made on the bone material. The bones date to the Early Mesolithic, the Late Mesolithic and the Early Metal Period (Table 2). Some changes in the hunted species can be detected: all the dated elk bones from Rahakangas 1 are Early Mesolithic, while the beaver bone is of a Late Mesolithic date. A Late Mesolithic date was obtained also for a fish sample from the

Table 4. The species identified in the burnt bone material from excavations at the Rahakangas 1 site, 20092010. NISP = number of identified specimens.

\begin{tabular}{|l|r|r|}
\hline Taxon & NISP & \multicolumn{1}{l|}{ Weight (g) } \\
\hline Alces alces (Eurasian elk) & 27 & 49.18 \\
\hline Castor fiber (Eurasian beaver) & 55 & 23.78 \\
\hline Canidae cf. Vulpes vulpes (dog family, cf. Red fox) & 1 & 0.03 \\
\hline Martes martes (European pine marten) & 10 & 0.80 \\
\hline Ruminantia (ruminants) & 58 & 17.79 \\
\hline Mammalia (Indet. mammals) & $>2251$ & 588.11 \\
\hline Aves/Mammalia (birds/mammals) & 22 & 2.47 \\
\hline Gavia sp. (Indet. diver) & 2 & 0.25 \\
\hline Lagopus lagopus (Willow grouse) or Lagopus muta (Rock ptarmigan) & 1 & 0.14 \\
\hline Anatidae (Anas family) & 1 & 0.09 \\
\hline Aves (birds) & 3 & 0.15 \\
\hline Esox lucius (Northern pike) & 270 & 16.48 \\
\hline Perca fluviatilis (European perch) & 4 & 0.11 \\
\hline Coregonus lavaretus (Common whitefish) & 6 & 0.06 \\
\hline Cyprinidae (Cyprinid fish) & 75 & 3.23 \\
\hline Teleostei (Bony fish) & 1250 & 20.55 \\
\hline Indeterminata & 5537 & 183.06 \\
\hline SuM & $\mathbf{9 5 7 3}$ & 906.28 \\
\hline
\end{tabular}


nearby site Kaiskunsärkkä 1, located on the northern side of the ancient lake (Figure 3). A fish sample from Rahakangas 1 was dated to the Early Metal Period. These dates thus indicate a long tradition of fishing on the shores of Lake Sarvinki until its unfortunate draining in 1743.

\section{A lithic perspective}

The lithic collection includes a small amount of slate, quartzite, and exotic flint artefacts together with the more abundant quartz (Table 1). Some ground and polished stone tools, that is, an axe, a slate pendant, and a grinding plate and its fragments, have also been found. The proportion of formal quartz tools and cores is modest ( $2 \%$ combined), and debitage and shatter dominate the quartz assemblage (Table 1). In general, the size of the chipped lithic artefacts seems small at Rahakangas. Artefact weight provides a simple and easily replicable measurement of the Rahakangas 1 quartz material. However, comparing the weight of the Rahakangas 1 quartz artefacts to those from other sites is hindered by the lack of published data on Mesolithic lithic collections from Finland. Data from two large unpublished coastal Mesolithic sites, Hietaranta and Rimpikangas in western Finland, are presented for comparative purposes in Table 5. A combination of measures shows that the weight of the quartz artefacts is smaller at Rahakangas 1 than at Hietaranta and Rimpikangas. This agrees well with our intuitive field experience, which suggested a relatively small size for the Rahakangas 1 quartz material. It also agrees with the flint data presented below. The low weight of quartz artefacts indicates small size of flaking products and residual cores. In addition to functional needs, this may result from the need to conserve toolstone and/or from the small size of the original parent cores. The two latter options are expected to be related to raw material availability and the costs of carrying lithic material over great distances.
The spatial distribution of quartz shows both a background scatter and three dense quartz concentrations, suggesting two behavioural processes in operation at the site (Fig. 4). These are the use and abandonment of individual quartz artefacts all over the excavated site area, and a spatially segregated and concentrated reduction of cores and/or use of quartz at specific locations, such as inside the house-pit.

The key points of the Rahakangas 1 flint assemblage can be summarized as follows: a wide raw material variation (a minimum of seven varieties), a presence of both Cretaceous and Carboniferous flint, a lack of cores, a presence of many retouch/trimming flakes $(26 \%)$, a relatively small debitage and tool size (median length $9 \mathrm{~mm}$, maximum $19 \mathrm{~mm}$; see Figs. 5 and 6), a scattered spatial distribution over the site, and a lack of concentrations (Fig. 4). A breakdown of the chipped flint shows that flakes dominate the collection, retouched blades are the most numerous among the tools, and cortex on artefacts is rare (Table 6).

The small amount of flint, the lack of cores, the small number of cortical artefacts, the large percentage of retouch flakes and the small size of the lithics in general imply that flint was relatively rare, heavily curated, and that flint tools and possible cores passed through the Rahakangas 1 site quickly. This implies that foragers were relatively mobile, and/or that the site was used on a short-term basis. This is in contradiction with the house-pit located at the site. The presence of a house-pit therefore suggests that changes in mobility and spatial organisation took place over time.

The scattered spatial distribution over the site and the lack of flint concentrations suggest that the Rahakangas 1 flint collection is not the result of a single occupation, but instead has accumulated at the site gradually over time. This is also supported by

Table 5. Comparison of quartz artefact weights between Rahakangas 1and two coastal sites, Hietaranta in Honkajoki and Rimpikangas in Isojoki (Hertell, unpublished data).

\begin{tabular}{|l|c|c|c|c|r|r|}
\hline Site/artefact weight $(\mathbf{g})$ & N & Mean & Median & Min & Max & Std \\
\hline Eno Rahakangas 1, sample & 590 & 1.1 & 0.1 & 0.1 & 49.5 & 4.1 \\
\hline Honkajoki Hietaranta 2001 excavation & 2106 & 2.3 & 0.2 & 0.1 & $>500.0$ & 18.2 \\
\hline Isojoki Rimpikangas 1999 excavation & 449 & 3.3 & 1.0 & 0.1 & 132.2 & 10.5 \\
\hline Isojoki Rimpikangas 2000 excavation & 221 & 3.5 & 0.7 & 0.1 & 166.7 & 12.3 \\
\hline
\end{tabular}




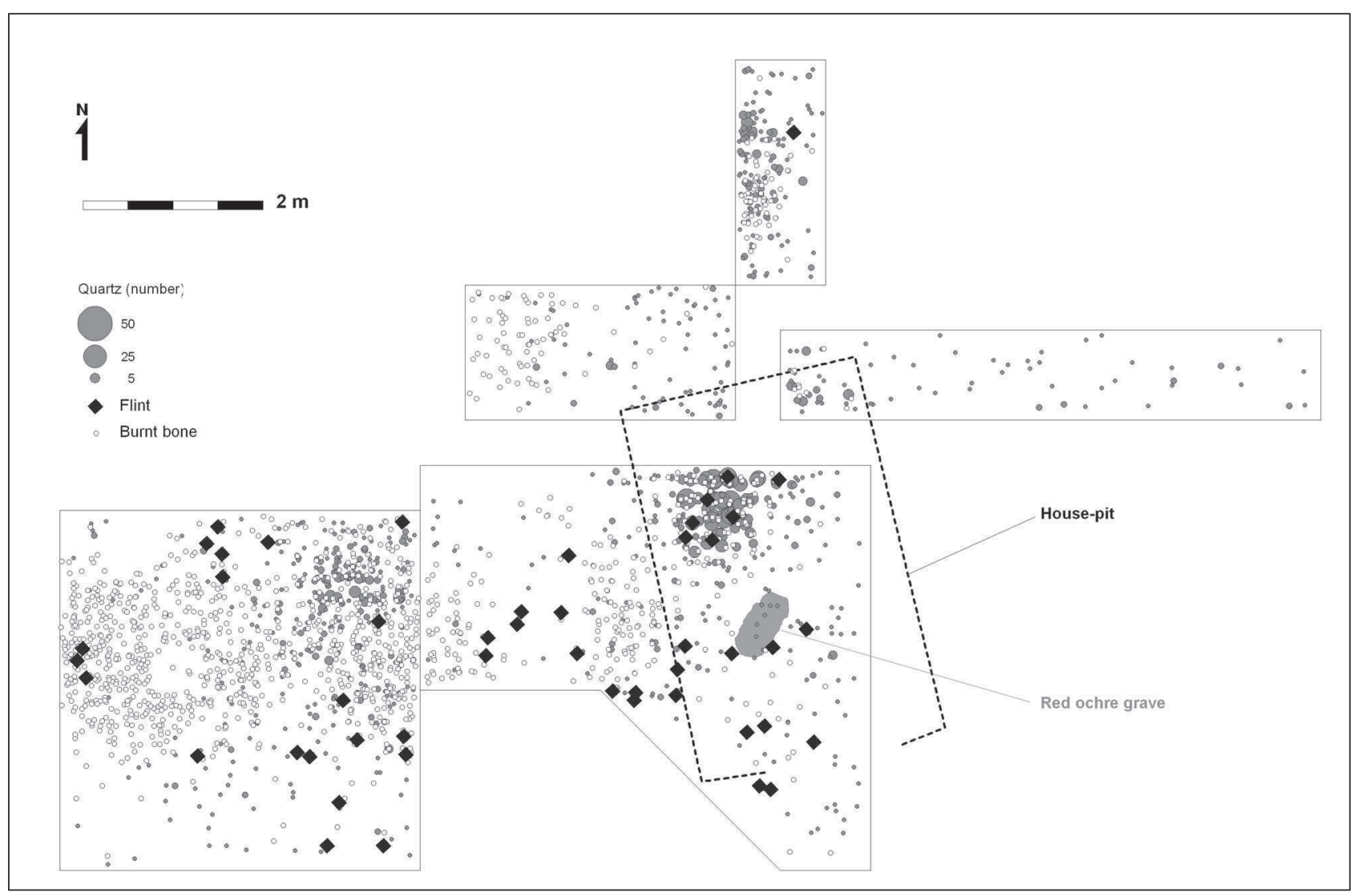

Figure 4. The spatial distribution of quart, burnt bones and flint at Rahakangas 1.

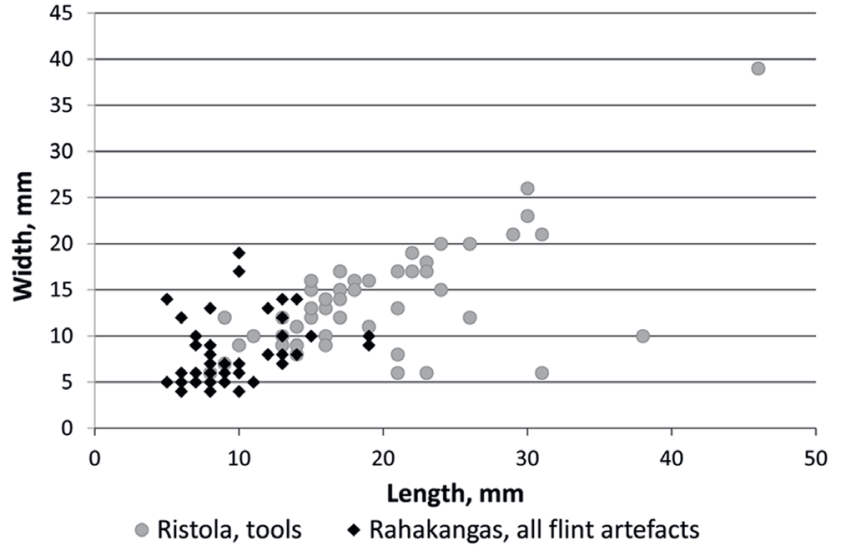

Figure 5. Comparison of the available flint data from Rahakangas 1 and Ristola (Takala 2004). The fraction including large lithics is missing from the Rahakangas 1 site.

the presence of several raw material varieties, which show that debitage and tool blanks originate from multiple cores, tools and knapping episodes. A high diversity of raw materials has been documented also for other published Mesolithic flint assemblages from Finland, i.e., the Helvetinhaudanpuro, Saarenoja 2, Ristola, and Syväys 1 assemblages (Jussila et al., 2007; 2010; Hertell and Manninen 2006; Takala 2004). This suggests a common pattern in flint assemblage formation at these sites. Furthermore, the presence of two major raw material varieties, Cretaceous and Carboniferous flint, has been reported previously at these as well as other Mesolithic sites in south-eastern Finland and Russia (Jussila et al., 2007; 2010; Takala 2004). In addition, flint was imported into the area during the later Stone Age as well. This information, together with the dated occupation phases of Rahakangas, suggests that the flint accumulated at the site slowly over thousands of years.

\section{The red ochre grave in Rahakangas 1}

Inside the house-pit, at a depth of $30-45 \mathrm{~cm}$ beneath the ground surface, an oval feature coloured by red ochre and only $70 \times 40 \mathrm{~cm}$ in size, was discovered (Figures 7-8). The presence of a grave was confirmed when small and fragile pieces of tooth enamel and one intact tooth were discovered in the south-western part of the grave. Human remains are not commonly preserved in Finnish graves because the acid 


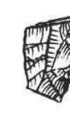

点

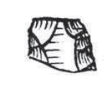

棒 $\sim$

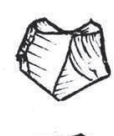

算 $\sim$
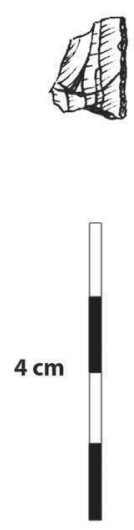

$\triangleright$

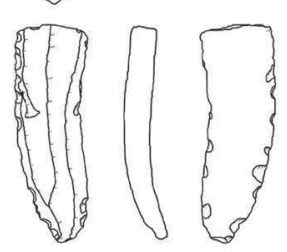

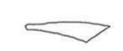
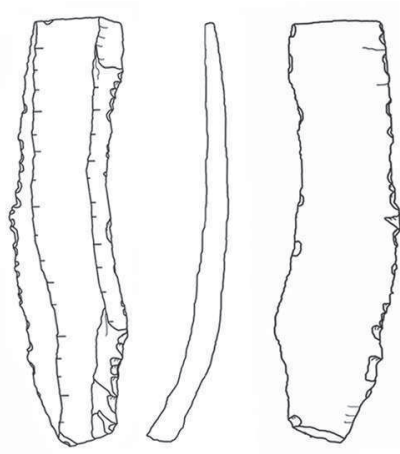

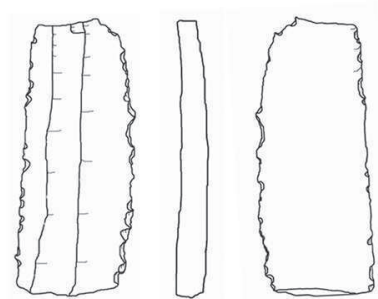

$\longleftrightarrow$

ख
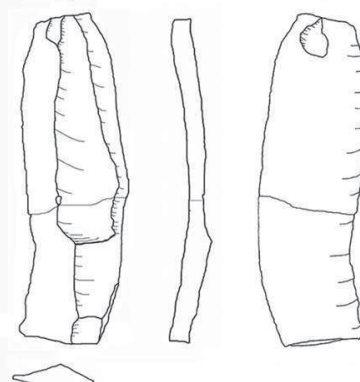

Figure 6. The largest tools and tool fragments from the Rahakangas 1 site (left) and blades from the Syväys 1 site (right, Hertell and Manninen 2006).

Table 6. Data on Rahakangas chipped flint artefacts from the 2009 and 2010 field seasons.

\begin{tabular}{|l|c|}
\hline Artefact type & N \\
\hline Blade/blade fragment & 7 \\
\hline Flake/flake fragment & 35 \\
\hline Debris/shatter & 5 \\
\hline Undefined & 2 \\
\hline Artefact total & 49 \\
\hline SUM retouched tools & 7 \\
\hline Tool/tool fragment & \\
\hline Retouched blade & 4 \\
\hline Biface & 1 \\
\hline Scraper & 1 \\
\hline Tang/piercer & 1 \\
\hline Tool total & 7 \\
\hline Blade/flake, dorsal cortex (\%) & \\
\hline 0 & 39 \\
\hline$<33$ & 1 \\
\hline$<66$ & 0 \\
\hline$<100$ & 2 \\
\hline Type of platform remnant & \\
\hline Cortical & 2 \\
\hline Facetted & 11 \\
\hline Flat & 11 \\
\hline Punctiform & 2 \\
\hline Platform intact total & 24 \\
\hline
\end{tabular}

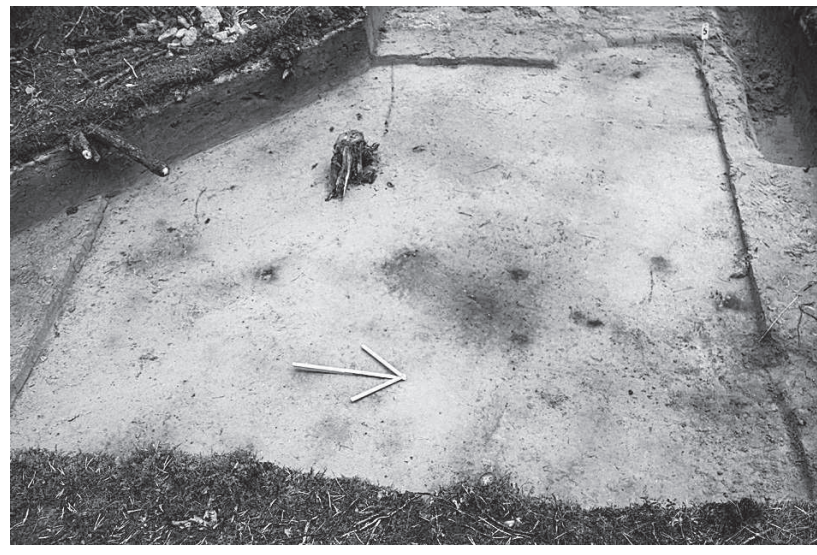

Figure 7. The Rahakangas 1 red-ochre grave in excavation level 6 (30 cm below the ground surface). Photo: P. Pesonen 2009.

identify it as a front tooth (osteologist Kati Salo, pers. comm.; Fig. 9).

The teeth were found in an area of c. $25 \times 25 \mathrm{~cm}$, where the red ochre cover was most intense. Judging from the position of the dental remains, the orientation of the deceased had been head towards south-west. Around the head end of the grave there was lightcoloured sand outside the patch of red ochre (Figure 8 ). The bottom of the grave was flat. There were no traces of a possible larger pit around the red ochre feature. The head end of the grave was taken to the 
red ochre deep red ochre

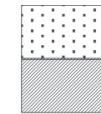

red and grey sand light brown sand

0

40

$80 \mathrm{~cm}$
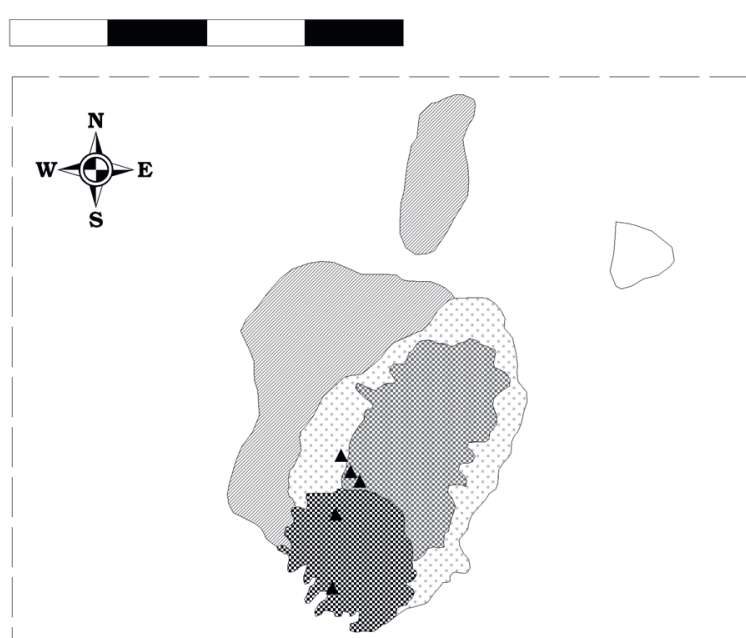

Excavation level $7(35 \mathrm{~cm})$

Figure 8. The red-ochre grave during the excavation.

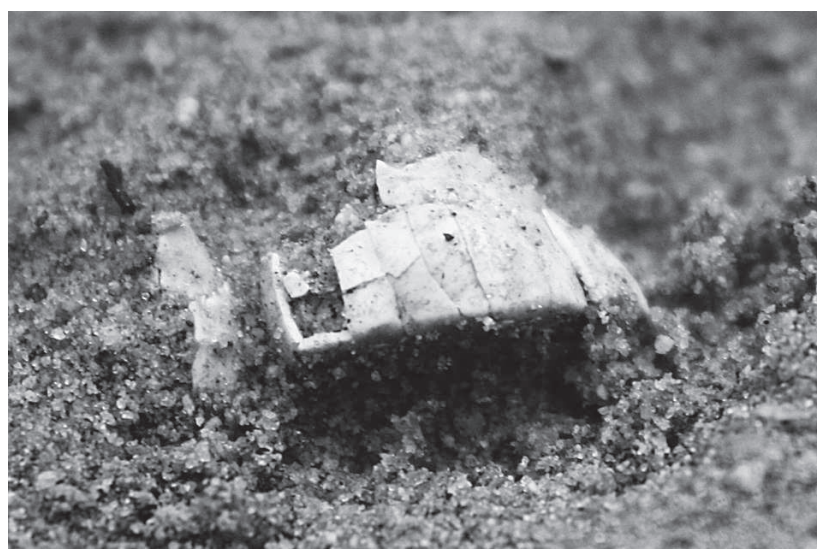

Figure 9. An incisor in situ. Photo: E. Hertell 2009.

laboratory en bloc to be excavated later. Two more teeth, a premolar and a molar, consisting only of tooth enamel, have subsequently been uncovered in the laboratory. The sand clod has not been completely excavated yet. The molar tooth belongs to a child or a juvenile, judging from the limited wear on it (Kati Salo, pers. comm.). What we have found at Rahakangas 1 is most likely a single burial of a child or a juvenile. Also the small size of the red ochre feature supports this interpretation.

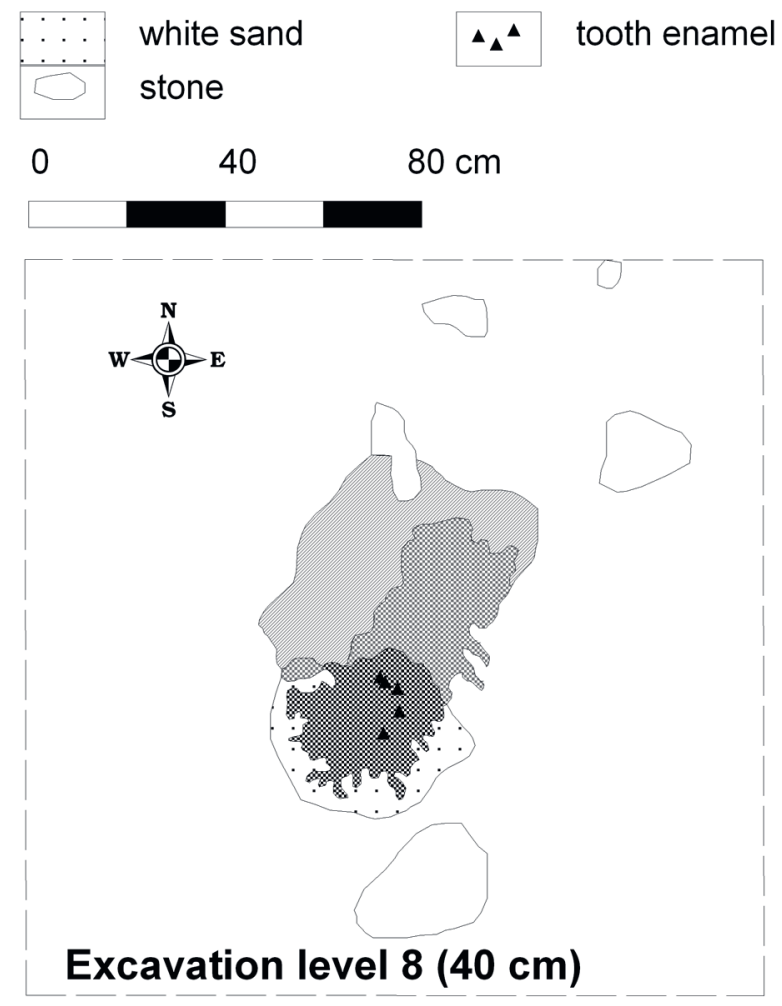

There were no grave goods or objects in the grave. No settlement finds that could have ended up in the grave with the grave filling were detected, either. It is possible that grave goods made of organic material were originally put in the grave, but if this is the case, they were not preserved. In the multi-period cemetery of Jönsas in Vantaa only two Mesolithic graves of a total of 23 contained grave goods. No round and sleek water-worn stones were found in the Rahakangas 1 grave, either - a feature sometimes present in Finnish burials, for instance in Jönsas and in the Vaateranta cemetery in Taipalsaari (Purhonen and Ruonavaara 1994, 89; Katiskoski 2004, 116). There is no evidence that would indicate that the grave was visible above the ground.

Due to the lack of preserved grave objects, radiocarbon dating was the only possibility to determine the age of the grave. The teeth could not be dated because only tooth enamel was preserved. One piece of charcoal from the sand filling of the grave was chosen for radiocarbon dating, and yielded a Late Mesolithic date, 8600-8408 cal BP (Table 2). According to the observations made during the excavation, there had been no later disturbance in the grave area. In Tågerup, Sweden, charcoal from the grave filling was 


\begin{tabular}{|l|c|c|}
\hline Site & Number of Mesolithic graves & Preserved human osteological material \\
\hline Joensuu Rahakangas 1 & 1 & $x$ \\
\hline Kajaani Äkälänniemi & 1 & $x$ \\
\hline Kuortane Haavistonharju & 1 & \\
\hline Kuusamo Jokela & 1 & \\
\hline Lieto Knaapin hiekkakuoppa & 3 & \\
\hline Vantaa Gröndal & 1 & \\
\hline Vantaa Jönsas & 23 & \\
\hline
\end{tabular}

Table 7. Mesolithic burials in Finland (Pesonen et al., in press; Schulz 1999; Sarvas 1986; Lappalainen 2007; Räty 1995; Kankkunen 2003; Purhonen and Ruonavaara 1994; Leskinen and Pesonen 2008).

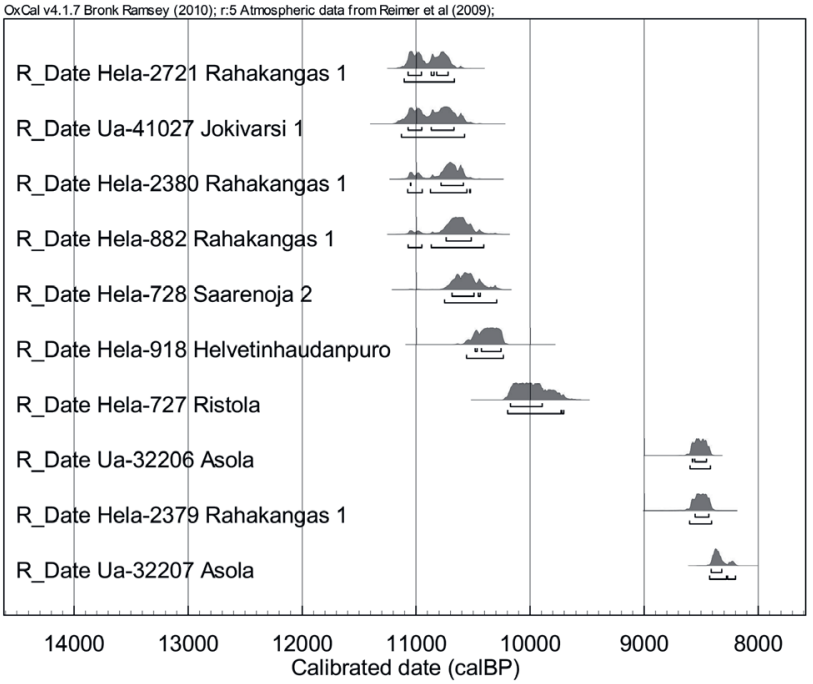

Figure 10. Published radiocarbon dates on Early Mesolithic flint assemblages in Finland (Jussila et al., 2007, 2010; Leskinen and Pesonen 2008; Pesonen et al., in press; Takala 2004).

also used for dating, as the skeletal remains lacked sufficient collagen. At that site the typological dating of the grave goods supported the absolute dating (Ahlström 2003, 479).

The Mesolithic burials in Finland do not show a uniform pattern in the orientations of the graves. Human remains, i.e., pieces of tooth enamel, have been reported only from the Äkälänniemi site in Kajaani (Schulz 1999) and from Rahakangas 1. However, teeth have been found in several Neolithic ${ }^{1}$ burial grounds in Finland, for instance in a collective grave at the Kanava site in Joroinen and also in the Vaateranta cemetery (Mustonen 2005; Schulz 2006; Katiskoski 2004). The Finnish Mesolithic burials are individual burials except for the Jönsas cemetery and the Knaapin hiekkakuoppa burial site in Lieto (Table 7). Red ochre is present in the Mesolithic graves with the exception of one burial at Knaapin hiekkakuoppa (Kankkunen 2003).
The red ochre grave at Rahakangas 1 was an exceptional discovery, since only seven Mesolithic burial sites with a total of $c .30$ burials have so far been found in Finland (Fig. 1; Table 7). The burials are usually dated to the Mesolithic on the basis of an adjacent settlement site and/or the presence of red ochre and the lack of grave goods. In a few cases, human teeth from Finnish Neolithic graves have been radiocarbon dated, but the results have been remarkably younger than expected, and they have not been fully accepted (Schulz 2006; Edgren 1999). Skull pieces found in a cremation grave at the Vaateranta site have, however, yielded results that are in accordance with the dating of the settlement site (Katiskoski 2004).

\section{Discussion}

After the cold Younger Dryas climatic episode, deglaciation gained speed and new land emerged rapidly in eastern Fennoscandia. During the first occupation phase of the Lake Sarvinki area, the River Pielisjoki valley and the Pielinen Ice Lake formed a north-eastern projection of the Yoldia Sea for a short time. Very soon the sea retreated and the present lakes Pielinen and Saimaa were formed with River Pielisjoki as a connecting waterway between them. Until its drainage in 1743, Lake Sarvinki remained stable through the times.

It is likely that the conditions by the open shores of the Yoldia Sea were not attractive to the pioneers arriving from the post-Swiderian cultural sphere for several reasons: 1) the Yoldia Sea was not very productive, 2) cold winds from the glacier made the unsheltered shores of the sea hostile, and 3) the hunters were not adapted to the marine environment because they originally came from a region where hunting of terrestrial mammals was predominant. The condi- 
tions by Lake Sarvinki would therefore have better fitted the requirements of the pioneer settlers. Their requirements were probably met by an abundant elk population thriving in the young birch tree forests.

The history of the large inland lake basins complicates the modelling of the Mesolithic settlement in the inland parts of eastern Fennoscandia. For example, the evidence of Mesolithic sites has been almost completely inundated by the Holocene transgression of the Lake Saimaa complex (Saarnisto 1970). The area around Lake Pielinen, another large lake basin located north of the Sarvinki area, is a good candidate for the study of the preferences of the pioneer settlers. There are no sites in the area that would be contemporaneous with the Late Preboreal Ice Lake stages of the Pielinen basin, whereas a number of sites are dated to the Late Mesolithic (Pesonen et al., 2010). This is in agreement with the argument that the earliest settlers did not routinely occupy these hostile and cold shores.

The two sites in the Lake Sarvinki area, Rahakangas 1 and Jokivarsi 1, as well as the Kirkkolahti 1 site near Lake Jänisjärvi, are so far the only radiocarbon-dated Early Mesolithic sites in North Karelia and northern Russian Karelia. The Sarvinki sites were located on the shore of a relatively small lake, perhaps because of the reasons mentioned above. The larger water bodies of Lake Saimaa and Lake Pielinen were probably preferred during the later stages of occupation once the lake-shores had stabilised and the climate had become warmer. A Late Mesolithic occupation phase in the Lake Sarvinki area took place some 1500 years after the pioneer phase in the Boreal period, as indicated by several radiocarbon dates. The Rahakangas 1 site was still used as fishing station thousands of years later, in the Early Metal Period.

Our preliminary analysis of the lithic material shows that quartz and flint artefacts are remarkably small at the Rahakangas 1 site. The sites referred to for comparison (see Figs. 1, 5, and 6, and Table 5) are located on the shores of larger water basins. The differences in artefact size may be linked to the variability in foraging options, mobility strategies, and site use in these two different macro environments. The sites located next to small lakes may have been ephemeral or temporary in nature when compared to those in the coastal areas or on the shores of large inland water basins.

The presence of exotic flint is well attested at Mesolithic sites, but high-quality contextual dates are relatively rare for the flint finds in Finland. The radiocarbon evidence from Rahakangas 1 and other Early Mesolithic sites suggests that exotic flint was brought to southern Finland over a period of at least c. 600 radiocarbon years, i.e., possibly one thousand calendar years, if younger sporadic occurrences are excluded (Fig. 10). However, connecting AMS-dates with flint finds at Rahakangas 1 is problematic as the site has been used many times over the millennia and flint artefacts are scattered over the site. In principle, the house-pit provides the best context for dating the artefacts at the site, but no date exists for the house at present. AMS-dates show three periods of site use at Rahakangas 1, and the house-pit may well date to any of these: the Early or Late Mesolithic, or the Early Metal Period. The Late Mesolithic red ochre grave located inside the house may suggest that the house and the flint artefacts in it are all Late Mesolithic. Assuming that the Early Mesolithic AMS-determinations from Rahakangas 1 date some of the flint artefacts as well, the Late Mesolithic house-pit would imply that flint accumulated sporadically at the site over 1500 years. On the other hand, flint finds are also known from the Early Metal Period sites in the eastern Fennoscandia, and the pit may well be of a relatively late date. We hope that new AMS-samples will shed further light on the formation of the Rahakangas 1 site.

In sum, we argue that flint materials originating from various sources along the Lithuania-Belarus to northwestern Russia axis ended up at Rahakangas 1 gradually over time. Based on the available radiocarbon data, the flint accumulation seems to have started in the Early Mesolithic and possibly continued, on and off, for several hundreds of years. We suggest that the described characteristics of the Rahakangas 1 flint assemblage are the result of exchange between groups living across the enormous north-eastern European forest zone covering hundreds of thousands of square kilometres, and of the use of exotic flint within the local hunter-gatherer settlement system around Lake Sarvinki. Because of the exchange network, flint became available in small quantities for the North Karelian hunter-gatherers who extended the use-lives 
of the small pieces by reducing and curating them until exhaustion.

Several Fennoscandian Mesolithic and Neolithic burial grounds have been used over long periods of time. The Jönsas burial ground in Vantaa, southern Finland, was used during the Mesolithic and the Neolithic (Purhonen and Ruonavaara 1994). The Zvejnieki burial ground in Latvia has been used for over four millennia, beginning already in the Early Mesolithic (Zagorska 2006, 13). Also the burials in Popovo, Russia represent both the first pioneer settlement and a later phase. The graves were furnished with red ochre and in a few cases with grave gifts and pieces of charcoal. Ritual pits with animal bones and red ochre were also found at the site (Oshibkina 1989, 403, 411-412). The Popovo site is connected to the Veretye cultural complex, the probable origin of the first settlers of North Karelia.

The tooth enamel finds at Rahakangas 1 are a rare example of preserved human skeletal remains from Stone Age in Finland. Mesolithic burial sites with preserved organic material in the nearby areas of Finland include Oleniy Ostrov, Popovo, Peschanitsa, and Minino 1 and 2 in Russia, Zvejnieki in Latvia, Skateholm and Tågerup in Sweden and Vedbæk Bøgebakken in Denmark (Fig. 1). Important Mesolithic burial grounds with no preserved osteological material include Chernaya guba and Siamozero in Russia, and Spiginas and Duonkalnis in Lithuania (Oshibkina 2008; Fig. 1).

It is possible that only one individual became buried at Rahakangas 1 because the site was used only on a temporary basis. Single graves have been interpreted as signs of rather mobile communities, which would have buried their dead during seasonal migrations or pioneer expeditions. These graves usually represent individuals of different ages and both sexes (e.g., Sulgostowska 2006). The Mesolithic burial sites differ from each other in several aspects including the number of burials and individuals, the location of graves at or outside the settlement site, the orientation of graves and the age and the sex of the individuals buried. The use of red ochre is, nevertheless, more or less common for all burials. This custom links Rahakangas 1 and the Mesolithic Finland to the burial practices of eastern Fennoscandia and north-western Russia.

\section{Conclusion}

The key points in illuminating the settlement history of the Lake Sarvinki area are derived from environmental history, the lithic assemblage and the presence of a grave. According to the current knowledge, the Early Mesolithic subsistence economy in the Lake Sarvinki area was based on hunting elk, while more versatile hunting and fishing economies were practiced later on in the area. Mobility is indicated by both the composition of the flint assemblage and the presence of a single grave. While the stabilisation of the environment c. 500 years after the retreat of the glacier allowed people to colonize the area, the settlement was by no means permanent by nature. The available evidence suggests that local groups occupied the area sporadically during the Early and Late Mesolithic. These groups had contacts to areas further east and were supplied with some flint through the exhange networks. The current evidence suggests gradual changes in land-use patterns and settlement organization in the Lake Sarvinki area through time: from short-term site occupation and hunting of large terrestrial mammals to fishing stations, pit-houses and longer periods of site occupation.

\section{Acknowledgements}

This study has been partly financed by the following projects and foundations: the Argeopop project (University of Helsinki), the University of Helsinki Chancellor's Travel Grant, the Finnish Graduate School in Archaeology, the Foundation for the Advancement of Karelian Culture, and the Oskar Öflund Foundation.

\section{Note}

1. The beginning of Neolithic in Finnish context means the beginning of pottery use, not farming.

\section{References}

Ahlström, T. 2003. Mesolithic Human Skeletal Remains from Tågerup, Scania, Sweden, in L. Larsson, H. Kindgren, K. Knutsson, D. Loeffler and A. Åkerlund (eds.), Mesolithic on the Move, Papers presemted at the Sixth International Conference on the Mesolithic in Europe, Stockholm 2000, 478484. Oxford, Oxbow Books.

Äyräpää, A. 1951. Die ältesten Steinzeitlichen Funde aus Finnland. Acta Archaeologica XXI (1950), 1-43.

Birks, H.J.B. and Birks, H.H. 2008. Biological responses to rapid climate change at the Younger Dryas-Holocene 
transition at Kråkenes, western Norway. The Holocene 18(1), 19-30.

Björck, S. 1995. A review of the history of the Baltic Sea, 13.08.0 ka BP. Quaternary International 27, 19-40.

Bronk Ramsey, C. 2009. Bayesian analysis of radiocarbon dates. Radiocarbon 51(1), 337-360.

Carpelan, C. 2008. On the history and recent studies of the 'Antrea Net Find'. In M. Lavento (ed.), Karelian Isthmus Stone Age Studies in 1998-2003. Iskos 16, 88-127. Helsinki, The Finnish Antiquarian Society.

Cramp, S., Simmons, S., Ferguseon-Lees, I.J., Gillmor, R., Hollom, P.A.D., Hudson, R., Nicholson, E.M., Ogilvie, M.A., Olney, P.J.S., Voous, K.H. and Vattel, J. 1986. Handbook of the Birds in Europe, The Middle East and North Africa. The birds of the Western Palearctic. Vol. 1. Ostrichs to Ducks. Oxford University Press. Oxford.

Donner, J. 2010. The Younger Dryas age of the Salpausselkä moraines in Finland. Bulletin of the Geological Society of Finland 82, 69-80.

Edgren, T. 1984. Kivikausi. In Y. Blomstedt (ed.), Suomen historia 1, 8-97. Espoo, Weilin \& Göös.

Edgren, T. 1999. Alkavan rautakauden kulttuurikuva Suomessa. In: P. Fågelberg (ed.), Pohjan poluilla: suomalaisten juuret nykytutkimuksen mukaan. Bidrag till kännedom av Finlands natur och folk 153, 311-333. Helsinki, Societas Scientiarum Fennica.

Forsberg, O. 2006. Jänisjoen reitin varhaisin asutus - inventointituloksia Värtsilästä ja Laatokan pohjoispuolelta. Muinaistutkija 1/2006, 2-16.

Hertell, E. and Manninen, M.A. 2006: Lisiä tietoihin PohjoisKarjalan säleistä ja säle-esineistöstä. Muinaistutkija 1/2006, 38-48.

Hertell, E. and Tallavaara, M. 2011. High mobility or gift exchange - Early Mesolithic exotic chipped lithics in Southern Finland. In. T. Rankama (ed.), Mesolithic Interfaces. Variability in Lithic Technologies in Eastern Fennoscandia. Monographs of the Archaeological Society of Finland, 11-41. Helsinki, The Archaeological Society of Finland.

Hyvärinen, H. 1966. Studies on the late-Quaternary history of Pielis-Karelia, eastern Finland. Societas Scientiarum Fennica, Commentationes Biologicae 29 (4), 1-72.

Hyvärinen, H. 1973. The deglaciation history of eastern Fennoscandia - recent data from Finland. Boreas, Vol. 2, 85-102.

Hyvärinen, H. and Rainio, H. 2000. Kallistuva Pielinen, in L. Lovén and H. Rainio (eds.), Kolin perintö - kaskisavusta kansallismaisemaan, 48-53. Joensuu, Metsäntutkimuslaitos \& Geologian tutkimuskeskus.

Jussila, T. and Matiskainen, H. 2003. Mesolithic settlement during the Preboreal period in Finland, in L. Larsson, H. Kindgren, K. Knutsson, D. Loeffler and A. Åkerlund (eds.), Mesolithic on the Move. Papers presented at the Sixth International Conference on the Mesolithic in Europe, Stockholm 2000, 664-670. Oxford, Oxbow Books.

Jussila, T., Kriiska, A. and Rostedt, T. 2007. The Mesolithic settlement in NE Savo, Finland and the earliest settlement in the eastern Baltic Sea. Acta Archaeologica vol. 78:2, 2007, 143-162.

Jussila, T., Kriiska, A. and Rostedt, T. 2010. Saarenoja 2 dwelling site. The missing link between the Early Mesolithic flint and quartz industry? Poster presented at the Eight International Conference on the Mesolithic in Europe, Santander 13th -17th 2010.

Kankaanpää, J. and Rankama, T. 2011. Spatial Patterns of the Early Mesolithic Sujala Site, Utsjoki, Finnish Lapland. In T. Rankama (ed.), Mesolithic Interfaces. Variability in Lithic Technologies in Eastern Fennoscandia. Monographs of the Archaeological Society of Finland, 42-63. Helsinki, The Archaeological Society of Finland.

Kankkunen, P. 2003. Lieto Knaapin hiekkakuoppa. Mesoliittisen kalmiston kaivaus. Unpublished excavation report in the archives of the National Board of Antiquities, Helsinki, Finland.

Katiskoski, K. 2004. The cemetery and dwelling site Vaateranta in Taipalsaari, southeastern Finland. Suomen Museo 2003, 81-125.

Koljonen, M.- L. 2008. Itämeren lohen levinneisyyshistoria. Riista- ja kalatalous - Selvityksiä 15/2008.

Lappalainen, M. 2007. Punamullan pauloissa. Kivikauden hautatutkimuksen tutkimushistoria Suomessa. Muinaistutkija 3/2007, 2-19.

Leskinen, S. and Pesonen, P. 2008. Vantaan esihistoria. Vantaa, the City of Vantaa.

Manninen, M.A. and Hertell, E. 2011. Few and Far between - an Archive Survey of Finnish Blade Finds. In T. Rankama (ed.), Mesolithic Interfaces. Variability in Lithic Technologies in Eastern Fennoscandia. Monographs of the Archaeological Society of Finland, 113-141. Helsinki, The Archaeological Society of Finland.

Matiskainen, H. 1996. Discrepancies in Deglaciation Chronology and the Appearance of Man in Finland. In L. Larsson (ed.), The Earliest Settlement of Scandinavia and its relationship with neighbouring areas. Acta Archaeologica Lundensia Series in $8^{\circ}$, No 24, p. 251-262. Lund, University of Lund.

Miettinen, A. 1996. Pielisen jääjärven kehityshistoria. Terra 108:1, 14-19.

Mustonen, R. 2005. Joroisten Kanavan punamultahaudat. In H. Ranta (ed.), Kentältä poimittua 6. Kirjoitelmia arkeologian alalta. Museoviraston arkeologian osaston julkaisuja no: 11, 19-30. Helsinki, National Board of Antiquities.

Myller, M.-L. 1999. Alansa ensimmäinen - järvenlaskuneuvoja Lassi Nuutinen. In K. Jalonen (ed.), Myrkyn kylvöä vai puhdasta luontoa-maaseutu, ympäristö ja historia. Turun yliopiston historian laitoksen julkaisuja 50, 123-137. Turku, University of Turku.

Nurminen, K. 2007. Kalanluulöytöjä Suomen neoliittisilta asuinpaikoilta. Muinaistutkija 1/2007, 2-17.

Oshibkina, S.V. 1989. The Material Culture of the Veretyetype. Sites in the Region to the East of Lake Onega. In C. Bonsall, (ed.), The Mesolithic in Europe. Papers presented at the third international symposium, Edinburgh 1985, 402-413. Edinburgh, John Donald Publishers.

Oshibkina, S.V. 2008. Mesolithic Burial Grounds and Burial Complexes in the Forest Zone of Eastern Europe. Anthropology E Archaeology of Eurasia, Vol. 46 no. 6, 46-70.

Påsse, T. and Andersson, L. 2005. Shore-level displacement in Fennoscandia calculated from empirical data. Geologiska Föreningens i Stockholm Förhandlingar 127, 253-268.

Pälsi, S. 1920. Ein steinzeitlicher Moorfund bei Korpilahti im 
Kirchspiel Antrea, Län Viborg. Suomen Muinaismuistoyhdistyksen Aikakauskirja XXVIII:2, 1-19.

Pesonen, P. 2002. Semisubterranean Houses in Finland - a Review. In H. Ranta (ed.), Huts and houses - Stone Age and Early Metal Age buildings in Finland, 9-41. Helsinki, National Board of Antiquities.

Pesonen, P. 2005. Sarvingin salaisuus - Enon Rahakankaan varhaismesoliittinen ajoitus. Muinaistutkija 2/2005, 2-13.

Pesonen, P., Simponen, L., Hertell, E., Mannermaa, K., Nyholm, M., Palm, J., Rostedt, T., Taipale, N. and Tallavaara, M. in press. First man in the Eastern Finland - a preboreal inland site with a red ochre grave in Joensuu Rahakangas 1. Proceedings of the Meso 2010 -conference, Santander, Spain, 2010.

Pesonen, P., Hertell, E., Manninen, M.A. and Tallavaara, M. 2010. Lieksan Viekin alueen arkeologinen inventointi. Unpublished survey report in the archives of the National Board of Antiquities, Helsinki, Finland.

Purhonen, P. and Ruonavaara, L. 1994. On Subsistence Economy at the Prehistoric Dwelling-Site of Jönsas in Vantaa, Southern Finland. In P. Purhonen (ed.), Fenno-Ugri et Slavi 1992. Museovirasto, arkeologian osaston julkaisuja n:o 5: 88-97. Helsinki, National Board of Antiquities.

Rankama, T. and Kankaanpää, J. 2008. Eastern arrivals in postglacial Lapland: the Sujala site 10000 calBP. Antiquity Vol. 88, n:o 318, 884-899.

Rankama, T. and Ukkonen, P. 2001. On the early history of the wild reindeer (Rangifer tarandus L.) in Finland. Boreas 30, 131-147.

Räty, J. 1995. The Red Ochre Graves of Vaateranta in Taipalsaari. Fennoscndia archaeologica XII, 161-172.

Reimer, P.J., Baillie, M.G.L., Bard, E., Bayliss, A., Beck, J.W., Blackwell, P.G., Bronk Ramsey, C., Buck, C.E., Burr, G.S. Edwards, R.L., Friedrich, M., Grootes, P.M., Guilderson, T.P., Hajdas, I., Heaton, T.J., Hogg, A.G., Hughen, K.A., Kaiser, K.F., Kromer, B., McCormac, F.G., Manning, S.W., Reimer, R.W., Richards, D.A., Southon, J.R., Talamo, S., Turney, C.S.M., van der Plicht, J., and Weyhenmeyer, C.E. 2009. IntCal09 and Marine09 radiocarbon age calibration curves, $0-50,000$ years cal BP. Radiocarbon, 51(4): 1111-1150.

Saarnisto, M. 1970. The Late Weichselian and Flandrian History of the Saimaa Lake Complex. Societas Scientiarum Fennica, Commentationes Physico-Mathematicae, Vol. 37.
Saarnisto, M. and Saarinen, T. 2001. Deglaciation chronology of the Scandinavian Ice Sheet from the Lake Onega Basin to the Salpausselkä End Moraines. Global and Planetary Change 31 (2001), 387-405.

Sarvas, A. 1986. Kuusamon esihistoria, in A. Sarvas and P. Sarvas (eds.), Kuusamon historia IV, 5-224. Kuusamo, the Municipality of Kuusamo.

Schulz, E.-L. 1999. Red-Ochre Grave at Äkälänniemi in Kajaani, North Finland. In M. Huurre (ed.), Dig it all. Papers dedicated to Ari Siiriäinen, 219-224. Helsinki, The Finnish Antiquarian Society and The Archaeological Society of Finland.

Schulz, E.-L. 2006. Joroisten Kanavan radiohiiliajoitukset, in P. Pesonen and T. Mökkönen (eds.), Arkeologia ja kulttuuri. Uutta kivikauden tutkimuksessa. Arkeologipäivät 2005, 132-137. Hamina, The Archaeological Society of Finland.

Sulgostowska, Z. 2006. Mesolithic mobility and contacts on areas of the Baltic Sea watershed, the Sudety, and Carpathian Mountains. Journal of Anthropological Archaeology, vol. 25 issue 2, 193-203.

Taavitsainen, J.-P. 1995. Antrean verkkolöytö ja topologia, in A. Henttonen, R. Henttonen, O. Korkeamäki and A. Pullinen (eds.), Kotiseutumme Antrea, 458-463. Helsinki, Antrea-seura ry. and Vuoksen Säätiö.

Takala, H. 2004. The Ristola Site in Lahti and the Earliest Postglacial Settlement of South Finland. Jyväskylä.

Tallavaara, M., Manninen, M.A., Pesonen, P. and Hertell, E. this volume. Radiocarbon dates and postglacial colonisation dynamics in eastern Fennoscandia.

Tikkanen, M. and Oksanen, J. 2002. Late Weichselian and Holocene shore displacement history of the Baltic Sea in Finland. Fennia 180: 1-2, 9-20.

Ukkonen, P. 2001. Shaped by the Ice Age. Reconstruction of the history of mammals in Finland during the Late Pleistocene and the Early Holocene. Helsinki, University Press.

Vesajoki, H. 1982. Varhaiset järvenlaskut muuttamassa Pohjois-Karjalan maisemia. Terra 94:1, 82-88.

Zagorska, I. 2006. The history of research on the Zvejnieki site, in L. Larsson and I. Zagorska (eds.), Back to the origin. New research in the Mesolithic-Neolithic Zvejnieki cemetery and environment, Northern Latvia. Acta Archaeologica Lundensia Series in 8, no 52, 5-24. Stockholm, University of Lund. 